\title{
Aligning with Sociopaths: Character Engagement Strategies in Highsmith's and Minghella's Talented Mr. Ripleys
}

\section{ABSTRACT}

Patricia Highsmith's stated reason for writing The Talented Mr. Ripley (1955) was to see if she could elicit empathetic engagement for her immoral protagonist Tom Ripley. Amongst other factors, she achieves her goal by allowing readers to align affectively with the protagonist's road to self-discovery. Her experiment culminates with Tom's fruition into an aggressive consumer, thus resolving his and the readers' apprehensions. On the other hand, Anthony Minghella's Ripley leaves more room for interpretation. In his interviews, the filmmaker states that he does not aim for his protagonist to remain the sociopath from Highsmith's novel. Instead, his story explores the absence of a father figure and how it affects his main characters. Consequently, he frames Tom as an underprivileged youth whose emotional instability brings about his demise. To this end, he employs victimization scenes, as well as moral disengagement cues. I argue that, amongst other factors, such an application of an industrytested design of emphatic concern elicitation obscures the filmmaker's initial intent. As a result, Minghella's Tom can be seen as a manipulative sociopath, as well as a victimized tragic hero.

Keywords: empathy elicitation, antisocial personality disorder, emphatic concern, antihero, enjoyment, character engagement, identification. 


\section{POSSIBLE INTERPRETATIONS}

The idea for this paper came after a screening of Anthony Minghella's The Talented Mr. Ripley (1999). I found a discrepancy in interpretation between my students and me. After several close viewings, I was sure I understood the film in the way that Minghella envisioned. I found insight into his intentions most notably in his screenplay. Yet the students' reactions correlated with my original perception of the film. The difference is this: either the film's protagonist is, as my students suggested, a brilliant though sociopathic social climber, or, as Minghella envisioned, an outsider spurred to violence by his unrecognized longing for a family. Coincidentally, the former case constitutes the essence of the source material that is Patricia Highsmith's novel of the same title (1955). However, it was Minghella's reinterpretation of Tom's romantic disposition that garnered most critical scrutiny. Minghella was criticized for having "larded the character with a conscience" (Minghella, Interviezes 97). The discussion ignored the fluidity with which the filmmaker had refined his protagonist. As a result, the film, which is possibly one of the best depictions of postwar American expatriate life, did not earn the accolades of Minghella's acknowledged masterpieces, like The English Patient (1996). ${ }^{1}$

Patricia Highsmith's Tom Ripley is often considered to be one of the most popular "sociopaths" in literature. The author's success lies in her ability to invent an identifiable character who throughout the Ripliad remains believably antisocial (Massey 167-68). Highsmith makes the nature of her experiment explicit when she writes: "[W] hat I predicted I would once do, I am doing already in this very book [Ripley $]$... that is, showing the unequivocal triumph of evil over good, and rejoicing in it. I shall make my readers rejoice in it, too" (qtd. in Schenkar ch. 11). Unsurprisingly, Tom's identifiability as a character makes for an interesting case study of empathy elicitation strategies, by which I mean storytellers' endeavours to induce and sustain empathetic engagement with their characters.

As far as the critical reaction is concerned, Highsmith's novels are often thought to have been eclipsed by their film adaptations. ${ }^{2}$ According to literary scholar Edward Shannon, such was the case with Minghella's Ripley (17). This seems to be true when comparing the immediate reception, however, "Minghella's film The Talented Mr. Ripley and the reissuing of her

\footnotetext{
1 Note that Patient won nine Academy Awards including "Best Director" for Minghella while Ripley earned five nominations but failed to win in any of the categories (see "Oscars").

2 Edward Shannon provides the earlier example of Alfred Hitchcock's 1951 adaptation of Highsmith's 1949 novel Strangers on a Train, which "earned more critical respect and attention" (17).
} 
novels" have brought about a positive reevaluation of her work (Wilson 463). We can accept that Minghella's craftsmanship may have been instrumental and it is probable that his attempt to revise Tom's character from Highsmith's antisocial antihero ${ }^{3}$ to a more relatable tragic hero earned a wider consideration for Ripley. Minghella's intention was thus to forgo Highsmith's bold narrative experiment for the sake of an industrytested strategy, aiming to elicit primarily sympathetic identification.

\section{EMPATHETIC ENGAGEMENT}

I base my understanding of empathetic engagement on the research of film studies scholars Berys Gaut and Amy Coplan. Firstly, Gaut maintains that narrative identification is "aspectual" in that a viewer's alignment with a character may be based on four aspects. He argues that those include the (1) affective, (2) perceptual, (3) motivational and (4) epistemic. This means that (1) imagining feeling what a character feels, (2) imagining seeing as a character sees, (3) imagining wanting what a character wants and (4) imagining believing what a character believes constitute the four alternative modes of empathetic engagement (137-52). This is an important distinction made in contrast to the common understanding of empathy as "feeling with others" which limits the phenomenon to the affective aspect (see Keen 83, Batson 15). Therefore, I understand empathetic engagement to be taking place when readers or viewers imaginatively experience psychological states congruously to a character, while simultaneously maintaining a clear self/other differentiation. Coplan makes the important argument that audience members remain aware of the boundaries between them and the character (147-49). More importantly, they are not limited to the states of the perceived characters as this would suggest that empathy and emphatic concern are mutually exclusive.

Emphatic concern (from now on referred to as sympathy) stands in contrast to the affective aspect of empathetic engagement in that it is reader or viewer specific. Narrative sympathy or the feelings of care and concern for a character's well-being is an other-oriented affective state that the character presumably does not experience (Batson 11). For an instance, if a protagonist, such as Tom, is publicly berated for his low economic status

3 Unlike the antiheroes of the gangster or film noir era, Highsmith's antihero is defined by his limited capacity to empathize with other characters. In this quality, he is arguably one of the precursors of such contemporary antisocial-antiheroes as Dexter Morgan of Dexter (2006-13), Walter White of Breaking Bad (2008-13), Frank Underwood of The House of Cards (2013-18), James and Alyssa of The End of the F***ing World (2017-) or Andrew Cunanan of The Assassination of Gianni Versace (2016). 
by a philandering socialite, chances are that readers might be angered by the assailant and become resentful of his privilege. Conceivably, the protagonist experiences similar sentiments. Thus readers align with the character both affectively (they and the character are angry with the socialite) and epistemically (both consider the socialite to be unjustifiably arrogant). In other words, readers experience empathy for the protagonist. However, if they additionally pity the character, then they are concurrently sympathizing with him. It is conceivable that in such a scenario the victimized protagonist might experience self-pity. It would seem that this affect is also congruous to that of readers. However, psychologist Nancy Eisenberg argues that other-oriented concern differs from concern for one's own wellbeing (1517). Nevertheless, this sort of empathy and sympathy based engagement is consistent with what Noel Carrol describes as a sympathetic bond ("On Some Affective Relations" 177-79). I delineate this distinction between the affective aspect of empathy and sympathy because herein lies the major difference in Highsmith and Minghella's strategies; in contrast to the novelist, the filmmaker is concerned with eliciting pity for Tom.

Returning to the previously described scenario, if the exchange causes us to feel hostility towards the philandering socialite without arousing pity for the protagonist, we are empathetically engaged, though we have not formed a sympathetic bond with the main character (this is most often Highsmith's mode). However, what impedes our sympathetic reaction is a lack of what Affective Disposition Theory (ADT) (Zillmann and Cantor) describes as a positive moral judgement. ADT's model for affective responding during suspenseful drama maintains that viewers pass a moral judgment on characters during the duration of a narrative. If a character continuously displays positive attributes and behaviour, such as helping others, the audience will most likely assess that character positively. According to Murray Smith's comparable model, the Structure of Sympathy, such judgement will lead to a "positive allegiance" or a sympathetic identification (83-86). However, if the character displays negative qualities or conduct, such as killing a friend, the resulting negative moral judgement might lead the viewer to form an antipathetic disposition. To counter this, storytellers can rely on moral disengagement cues. This device, which includes "dialog, innuendo, allusions," seeks to influence the audience's moral evaluation of characters (see Shafer and Raney 1038). A moral disengagement cue, therefore, will most often be a scene or a narrative event that justifies destructive behaviour. Minghella applies such cues during his adaptation's central murder scene.

Empathetic engagement strategies rely on the storyteller's application of what I call "empathy facilitators." These are various textual/visual cues and techniques that promote empathetic engagement in the affective, 
motivational, perceptual and epistemic aspects. I do not write "elicitor" or "elicitation" because these terms connote the assumption that the application of empathy facilitators guarantees empathetic engagement and that each facilitator autonomously carries elicitation potential. These devices are rarely effective when utilized independently. Instead, they need to be implemented as elements of a larger, sustained strategy targeting a given character. They include a wide range of theorist's and researcher's notions such as Wayne Booth's “inside views” (163), Edward Branigan's "projections" (132-33); Greg M. Smith's “emotion markers" (45), Karl Iglesias's "victimization scenes" and "virtue display" (70-73), Margrethe Brun Vaage's "POV structures" (159), and so on.

\section{ANTISOCIAL PERSONALITY DISORDER}

Among other aspects, Highsmith's novel owes its appeal to Tom's character being a believable representation of the antisocial personality disorder. According to the American Psychiatric Association, this affliction is characterized by "a failure to conform to lawful and ethical behaviour, and an egocentric, callous lack of concern for others, accompanied by deceitfulness, irresponsibility, manipulativeness, and/or risk-taking” (764). Highsmith convincingly characterizes Tom as having an egocentric drive, a lack of conscience, a limited ability to empathize, and most importantly an "incapacity for mutually intimate relationships" (764). Arguably Tom behaves within the boundaries of the Diagnostic and Statistical Manual of Mental Disorders' criteria of a sociopath.

In both the novel and the adaptation, at the bidding of a New York shipping tycoon, Herbert Greenleaf, Tom travels to Europe to convince the man's son, Dickie Greenleaf, to return home. Since Tom is the novel's focalizer, the reader is granted access to his perspective. This insight allows us to see that his attempts to befriend characters are underscored by selfserving pragmatism. In social interactions, Tom is often "God-damned bloody bored," all the while remaining self-monitoring (Highsmith 6). His first interaction in the novel is riddled with evidence of his emotional instability. His moods swing from "ecstatic moments" of fantasizing about his unwarrantedly golden future, to failure or fear-inspired sensations of "dizziness and nausea" $(36,86)$.

In the first chapter, Tom is cornered into a conversation by the aforementioned Herbert Greenleaf. During the exchange, Tom notes "that all his muscles had tensed” (7). Such behaviour, psychologist Martha Stout argues, is a telling quality of sociopaths. A "lack of conscience" may render such individuals incapable of experiencing a range of affects. To veil their 
lack of empathy, sociopaths might mimic the observed displays of emotions (Stout 6-7). This seems to be Tom's case, as the narrator informs us that the man remains untouched by Greenleaf's humiliating desperation while finding it necessary to fake "maniacal politeness." He becomes invested in the conversation only once he realizes that its outcome could afford him a paid trip to Europe.

Highsmith does not attempt to obscure Tom's emotional instability from the reader. Instead, she fearlessly reiterates the protagonist's objectionable feelings. It is possible that her antisocial-antihero might initially arouse the readers' curiosity. However, once his increasingly egotistical tendencies spiral into the homicidal domain, chances are that most readers will pass a negative moral judgement on Tom. Highsmith does not attempt to mitigate their resulting antipathy by using moral disengagement cues. ${ }^{4}$ Instead, she employs a sustained subjective narration, meaning she filters the story solely through her protagonist. Thus, Highsmith aligns the readers with Tom's affects, perspective, motivations and beliefs, relying most often on projections and inside views.

An example that demonstrates Highsmith's strategy here is her handling of Tom's second victim, Freddie Miles. In Minghella's adaptation, he is a philandering socialite who publicly berates Tom. Once Tom kills Dickie, the man he was supposed to convince to return to America, Freddie is one of the first characters who comes close to the truth. When he confronts Tom, Minghella relies on moral disengagement cues to mitigate the effects of his death. His revised character is substantially more contentious and condescending towards Tom. Minghella characterizes him in a manner that makes his death seem justified. Highsmith undertakes a very different approach. Her Freddie is not as demeaning as he is inquisitive. Still, when he confronts Tom, Highsmith describes him in the following manner: "Freddie was the kind of ox who might beat up somebody he thought was a pansy, especially if the conditions were as propitious as these" (109). She consistently details this character as "ugly, freckled" or "uninteresting." Highsmith uses "projections" or an empathy facilitator through which diegetic elements "reflect a character's mental state" thus making it explicit (Branigan 132-33). In this case, Tom's distaste for Freddie taints the descriptions of the character. Since Highsmith employs a fairly reliable narrator, readers are unlikely to doubt Freddie's objectionability. This aligns them perceptually with Tom; they both hold a similar view of Freddie.

4 Highsmith does include a few victimization scenes especially towards the novel's beginning; amongst others, Tom remembers his psychologically abusive aunt Dottie (Highsmith 28). However, the aim of those scenes is primarily to provide the reader with a credible backstory. Highsmith does not use this empathy facilitator in a manner that would render it a systematic element of her engagement strategy. 
Seconds before killing Freddie, Highsmith grants the reader the following insight into Tom: "He tried to think just for two seconds more: wasn't there another way out? What would he do with the body? He couldn't think. This was the only way out" (110). This subjective access into Tom is an example of an empathy facilitator that Wayne Booth calls an "inside view" (163-66). This device is closely related to Gérard Genette's notion of "internal focalization" which "represents a view of the fictional world through the eyes of a character" (Fludernik 153). More specifically, Highsmith constructs this inside view by using free-indirect speech. The narrator relates Tom's thoughts in a way that blurs the distinction between her and the protagonist. As with the previous example, Highsmith's narrator "becomes" Tom, transferring her authority onto him. Researchers have found that such use of free-indirect speech prompts the readers to perceive the thoughts and actions of the accessed character "to be more justified and rationalized" (see Dixon and Bortolussi 405-30; Kotovych et al. 260-88). In this case, Highsmith ensures that readers recognize Tom's reluctance to kill Freddie, as well as his inability to find an alternative to the situation. Those of them who believe the narrator's words will have aligned epistemically with Tom.

\section{A TRAGIC HERO}

Where Highsmith makes Ripley an exercise in making readers rejoice over "the unequivocal triumph of evil over good," Minghella takes a more inquisitive approach (qtd. in Schenkar ch.11). He admits his lack of interest in telling the story of a sociopathic killer. His aim is to make the audience perceive the "humanity" of Tom's character and to "see how that humanity gets corrupted" (Minghella, Interviezes 68). He envisioned Ripley to be the story of a "child who makes a small mistake, tries to cover it up, and in the process, sets off on a journey of bigger and bigger mistakes" (64). Undeniably, Tom searches for a family, but when his endeavours fail, he settles for a family name, appropriating the "Greenleaf” identity.

Many of Minghella's intentions are explicit in his screenplay, but only implicit in the film. Additionally, before seeing the adaptation, many viewers are likely to be preconditioned by Highsmith's novel, the film's promotional trailers ${ }^{5}$ or both. The effect of this may be that many of them may expect Tom to be a ruthless social climber, rather than Minghella's

5 Most versions of the trailer feature the following scenes: Tom spying through binoculars; Tom befriending Dickie; Tom performing chilling impressions; Tom handling potential murder weapons; Tom smiling sinisterly; Marge asking, "why is it when men play, they always play at killing each other?” 
misguided orphan. Moreover, critics and scholars reactions tend to focus on the film's sexual nuances, further obscuring Minghella's intended vision. For these reasons, we can observe a split in interpretations, especially of Tom's character. It is, therefore, unsurprising that where some see a vulnerable youth searching for love, others see an ambitious sociopath carefully calculating his interactions.

Matt Damon's depiction of Tom Ripley serves well to illustrate the point. His self-reflexive role required that he gradate between his performance and his character's performance. It is rarely clear whether Damon's Tom is being honest or whether he is performing in order to gain something. Still, the screenplay indicates that until his first murder, he remains transparent to Dickie and his girlfriend Marge. After Tom befriends Dickie, their short-lived camaraderie is interrupted by Freddie Miles's appearance. The estranged Tom sits alone on Dickie's sailboat as his friends frolic in the azure waters. Marge, recognizing his distress, approaches. In the screenplay, Minghella specifies in the action description that she is "conscious of [Tom's] isolation." "The thing with Dickie," she explains, "it's like the sun shines on you and it's glorious, then he forgets you and it's very very cold" (Minghella, Shooting Draft 29). The scene is meant to inform the audience that Tom feels jealous and betrayed. However, those primed to Tom's manipulativeness will assume him to be consciously eliciting Marge's compassion, alternatively veiling anger. Regardless of the filmed scene's interpretation, in the screenplay it is evident that Minghella intended for Tom to share in a moment of sincerity or connection. This is something that the novel's character does not do; he remains isolated by his "incapacity for mutually intimate relationships." Conversely, Minghella invents a string of scenes in which Tom solicits affection, or at least acknowledgement. These constitute his journey to find a family.

\section{TOM'S DESIRES}

Aside from Minghella's declared motivations, his revision of Highsmith's protagonist introduces an advantageous shift in the narrative. Tom's overt vulnerability and seeming desire for connection, in theory, bolsters the potential for viewers' sympathetic identification. Screenwriting theorist Karl Iglesias argues that virtue displays may include a scene in which "a character lets down his defences and shows his humanity in private moments, when he thinks no one is looking"; moreover, characters' displays of qualities such as "love, politeness, justice, generosity, compassion, and tolerance" bolster the audience's engagement with those characters (70-73). 
Scholars agree with Iglesias's hypothesis noting that positive attributes are conducive to a sympathetic bond, with some considering such qualities a prerequisite (see Tan 178; Carroll 173).

Many critics and theorists who undertake an analysis of Minghella's revision of Tom focus on the sexual aspect (see Bronski 41-43; Williams 49; Schwanbeck 357). For example, Edward A. Shannon argues that where Highsmith's Tom is "apparently asexual," Minghella introduces scenes that attest to his attraction to Dickie (22). Accordingly, Minghella presents Tom as a victim of bigotry and his own desires (18).

While Shannon's reading of Minghella's Tom is reductive, his observations about Highsmith's protagonist are certainly valid. In the novel, evidence as to Tom's sexual preferences is circumstantial. Highsmith's Tom harbours an apparent desire for Dickie's attention. But as romantic themes see no significant development in the novel, the unacknowledged physical attraction gives Tom an extra layer of complexity. More importantly, Highsmith contrives such ambiguities to confuse her readers. Her strategy is to withhold the information that, in reality, Tom desires not Dickie but his identity. Significantly, Tom is also unaware of this fact.

Highsmith produces several accounts to play with readers' expectations. Tom, for example, resents the fact that Dickie is having an affair with Marge. For Tom, Dickie functions as an aesthetic concept which, in his mind, the "unsophisticated-looking" Marge disrupts (Highsmith 15). Furthermore, Highsmith's narrator informs us of Tom's enjoyment of drag skit performances (29); we are told that he remembers keeping chaste company with "queer" men in New York, and that Tom recalls that one of his party routines included declaring to the group that he was giving both sexes up since he could not make up his mind as to which he preferred (62). This last example is most likely the reference that led Shannon to assert Tom's asexuality. On a side note, literary scholar Susan Massey notes that "Highsmith claimed that there was much of her own personality in Ripley's representation” (168). Much as Tom views Dickie as an aesthetic concept, one that he prefers to be untainted by the likes of Marge, it is conceivable that Highsmith held similar ideas about Tom. This might be the reason that she chose to keep her "favourite character" unencumbered by relationships with his fictional inferiors.

As the plot of Ripley unfolds, ambiguities as to Tom's desire persist. After having an unresolvable (in Tom's mind) argument with Dickie, the men decide to partake in a final farewell trip. As Dickie naps on the train, Tom observes him. Highsmith uses an inside view to relate the "crazy emotion of hate, of affection, of impatience and frustration [that] swelled in him, hampering his breathing" (76). She invites the reader to interpret Tom's state as an eruptive passion. In the subsequent sentence, 
Highsmith reveals that these emotions amount to Tom's wanting to "to kill Dickie" so that he can steal his identity. This realization seems to have a transformative effect on Tom. "The danger of it," the narrator relates, "even the inevitable temporariness of it which he vaguely realized, only made him more enthusiastic" (77).

Highsmith frequently reasserts Tom's unwitting search for a new identity. During the trip to Europe, he buys an English cap and revels in its potential to make him "look like a country gentleman, a thug, an Englishman, a Frenchman, or a plain American eccentric, depending on how he wore it" (25-26). As an enthusiast of impersonations, Tom observes that "the main thing about impersonation ... was to maintain the mood and temperament of the person one was impersonating, and to assume the facial expressions that went with them" (102). Highsmith produces several more foreshadowings of Tom's transformation when he revels in Dickie's clothes and jewellery (59).

The confusion concerning Tom's identity overarches Highsmith's empathy elicitation strategy. On the ground level, she keeps her readers submerged in Tom's experience using empathy facilitators such as the aforementioned projections. On the dramatic level, she ensures that the readers' confusion is aligned with that of the protagonist. The resulting engagement is both affective and epistemic. As mentioned, Tom remains at emotional extremes throughout the novel. His moods pivot when he feels his future is either secure or jeopardized. In such moments, Highsmith utilizes free-indirect speech to promote readers' alignment with Tom. For example, when Tom feels he has escaped justice, the narrator slips into the protagonist's thoughts, "he could have flown-like a bird, out of the window, with spread arms! The idiots! All around the thing and never guessing it!” (162). As the story develops, Tom grows more aware of the temporariness of his living under Dickie's identity. He knows he will have to move on, but Highsmith withholds the realization of his true identity until the novel's conclusion.

The author makes her character's inclination clear in the novel's final act. Once Tom is settled into Dickie's identity, he passes his evenings looking at his trophies, "feeling Dickie's rings between his palms and running his fingers over the antelope suitcase he had bought at Gucci's. ... He loved possessions.... They gave a man self-respect. ... Possessions reminded him that he existed" (193). Any trace of Dickie's stolen identity is eclipsed by the beautiful items. It is they that define the protagonist. Having experienced the protagonist's turbulent journey of self-discovery, the puzzled reader arrives at Tom's realization-he is a consumer with an undeniable aesthetic sensitivity. Tom, they find, may be strange, asexual, even sociopathic, but at least he can appreciate a good Gucci bag. 


\section{SYMPATHY AND ANTIPATHY}

In the film, Dickie, who has been murdered by Tom, becomes the chief suspect in Freddie Miles's murder. His father, Herbert Greenleaf, becomes involved in the investigation. Upon arrival in Europe, he says to Tom: "You know, people always say you can't choose your parents, but you can't choose your children" (Minghella, Shooting Draft 73). Minghella comments on Greenleaf's dialogue noting that "there's such a disappointment in his own son, and you feel that is the key to Ripley's escape: Herbert Greenleaf thinks the only person who is capable of behaving badly in the world is his own child" (Interviezes 68). Unlike in the novel, Herbert Greenleaf is at the heart of Tom's search for a family. Significantly, it is he who sits at the top of the film's most significant love triangle that is central to Minghella's engagement strategy. The absent father figure that Greenleaf represents is the presumed root of all the tragedy that occurs in the adaptation.

Returning to Edward A. Shannon's argument, he claims that Minghella's Tom desires to have a relationship with either Dickie or another character by the name of Peter Smith-Kingsley. Again, this detail is significant to the engagement strategy. Either Tom is capable of caring for others which, as the aforementioned studies show, is a trait that promotes audiences' empathetic engagement, or Tom is Highsmith's self-serving sociopath. If the latter was true, Minghella would need to embrace a more innovative empathy facilitation approach.

Wanting to convey Tom's attraction to Dickie, Minghella introduces a bath scene into the film. The two men play chess while Dickie soaks in the tub. After he rejects Tom's subtle offer of "sharing a bath" he "holds his look momentarily before flicking [Tom] with his towel" (Shooting Draft 22). While the sensual undertones are clear, the scene does not function as Tom's virtue display. The protagonist's desire, which otherwise could work as a sympathy eliciting quality, is contestable as many viewers might interpret Tom's seduction attempt as a display of his manipulativeness. Conceivably, such a scene might promote a negative moral judgement of Tom. Minghella, aware of this, reinvents Peter Smith-Kingsley. In the film, the character supports Tom during the murder investigation, until he too falls prey to Tom's murderous tendencies. Significantly, after Tom kills Dickie, he rouses the audience's antipathy which could be mitigated, amongst other things, by a virtue display. That considered, Minghella explains the symbolism of Tom's murders in the following manner: "Ripley [is] killing lust or desire or passion with Dickie and then killing the possibility of love with Peter" (Interviewes 76). In other words, the filmmaker assumes that the latter interaction held the potential for a mutually intimate relationship. Such 
development would have amounted to a significant virtue display, one that could have promoted a moral reevaluation of Tom.

A positive assessment of Tom matters to Minghella's strategy as it is a prerequisite to the sympathetic identification which the filmmaker wishes to elicit. An audience passes moral judgements independently of the empathetic engagement process; however, to identify sympathetically, they first need to empathize with the given character. In other words, empathetic engagement allows a positive moral judgment of a character to establish a sympathetic identification. This assumption is consistent with what film researchers Greg Smith and Carl Plantinga observe, namely that that sympathy entails processes constituent of empathetic engagement (see Film Structure 98; Moving Viewers 100). On the other hand, Highsmith's strategy relies primarily on facilitating empathy, which may be promoted despite a negative moral judgement. A reader may be empathetically engaged by Tom despite disliking him. For this reason, readers' antipathy towards the protagonist is not as grave a concern for Highsmith.

Minghella's revision of Dickie's murder manifests the sympathy elicitation efforts that are essential to his method. In the novel, Dickie's death is a result of Tom's cool calculations. Knowing his host's hospitality has run its course, Tom has the "brilliant" idea that "if he killed him ... he could become Dickie Greenleaf himself ” (Highsmith 77). The killing takes place as the two men set out to sail around San Remo. Though Minghella retains "the oar" as the weapon of choice, Tom does not contemplate the murder, nor does he distract his opponent before attacking him. Instead, he confronts Dickie about his feelings. He is ridiculed and threatened, and thus justified, before he "shocks himself" by striking. Moreover, the murder that follows plays out more like an act of self-defence. Dickie "launches himself at Ripley," and once the struggle ends, Tom "sprawls there, sobbing, next to Dickie, horrified by what he's done" (Minghella, Shooting Draft 39). Minghella's audience has sufficient motivation to suspend their moral judgment. In the screenplay, the filmmaker describes the killing's culmination as Tom "lying by Dickie at the bottom of the boat, in the embrace he's always wanted" (38). The image that plays on-screen shows Tom folded in a foetal position. He seems childlike next to Dickie's outstretched body. It is as if he is embracing an older brother-a compelling coda to a murder which escalated from Dickie's threats to beat some sense into Tom, who assumes the stance of an abused boy, pleading for Dickie to "stop it." Minghella explains that "it's quite possible in the way that I've staged and written the sequence on the boat that Dickie could have ended up murdering Ripley” (Interviezes 66).

The filmmaker goes further to mitigate the audience's feeling of antipathy. He encourages the viewer to pass a negative moral judgement 
on Dickie, to further justify his murder. He introduces into the narrative a new character, Silvana, Dickie's pregnant mistress. Dickie's mistreatment of the woman makes Tom's questionable talents for "forging signatures, telling lies, impersonating practically anybody" trivial by contrast (Shooting Draft 12). Silvana's eventual suicide is a moral disengagement cue that is meant to render Tom's murder of Dickie an act of justice.

Despite the use of empathy facilitators such as virtue displays, victimization scenes and moral disengagement cues, many viewers will likely fail to reevaluate their negative moral judgement of Tom after Dickie's murder. The reason for this is that Ripley's virtue demonstrations fail. His relationships with all the characters are selfserving. As the screenplay's Freddie Miles says to Tom, "you live in Italy, sleep in Dickie's house, eat Dickie's food, wear his clothes, and his father picks up the tab" (Shooting Draft 29). There is a single instance of Tom offering his help to Dickie by volunteering to take the blame for Silvana's pregnancy and death. Clearly, his proposal is duplicitous as it leaves Dickie "somehow in thrall to Ripley" (32). This leads me to believe that Minghella's engagement strategy would have been more successful had he supplemented it with at least one major virtue display after Tom's murder of Dickie. Arguably, Minghella demonstrates Tom's sensitivity and love of beauty in the film's opera scene; however, the mitigation of a murder would have likely required an act of selflessness or sacrifice for the benefit of another character (see Iglesias 72). Although in the latter part of the film, Tom seems to befriend Peter Smith-Kingsley, the relationship is again one-sided: Peter takes Tom into his home; he supports Tom during the investigation; he attempts to build Tom's selfesteem. Had Tom done something selflessly for Peter, viewers would likely have reevaluated their negative moral judgement.

\section{CAIN AND ABEL}

As Tom's interactions are self-serving, he seems to demonstrate the same incapacity to form intimate relationships as his literary counterpart. Interestingly, Herbert Greenleaf is the only character whom Tom, at least initially, does not want to disappoint. Having learned that his son is fond of jazz, Tom spends his time up until he departs for Europe, blindfolded, listening to records and trying to memorize the music of famous jazz artists. Once he arrives in Mongibello, he spies on Dickie through binoculars, learning about his girlfriends, Marge and Silvana, as well as the fact that Dickie named his boat, "Bird," after Charlie Parker. Considering the innocuousness of Tom's mission-to convince Dickie to return to 
America-viewers may find his overzealousness surprising, perhaps even menacing. At the least, they will recognize that Tom is highly motivated to fulfil Herbert Greenleaf's wish.

Minghella's film commences with the song "Lullaby for Cain" which proposes an analogy for Tom and Dickie's relationship. The filmmaker intersperses his narrative with suggestions of their brotherhood. Even Tom's bath scene innuendo, "we never shared a bath," references a sibling's childhood tub sharing. In their final confrontation, Tom says to Dickie, "you're the brother I never had. I'm the brother you never had" (Minghella, Shooting Draft 33). In effect, Tom's post-homicidal embrace of Dickie's body is evocative of Cain's shame at killing Abel.

The idea of Tom and Dickie's brotherhood is further reinforced by the character of Herbert Greenleaf. The character functions as the only father figure in the film. To Dickie, Herbert exists essentially as a source of an "allowance" and a constant reminder of his inadequacy. "That's my son's talent," Herbert tells Tom, "spending his allowance” (12). Minghella sees a parallel between the shortcomings of the would-be brothers. "Dickie's actions are almost as reprehensible and careless as Ripley's are," he argues. In this context, Herbert's insinuation that he would have preferred to have Tom as his son is telling of his fatherhood's condition (3). Moreover, after Dickie's presumed suicide, Herbert decides to transfer "a good part" of Dickie's income from his trust into Tom's name" (80). By doing so, he symbolically passes the remains of his fatherhood onto him. Thus Tom seems to find the family he sought. The irony is that Herbert will remain an absent father as he had been for Dickie. Tom and Dickie's fatherlessness is the implied root of their self-centeredness, anger and their resulting proclivity for violence. In other words, both men are essentially the same estranged, tragic character-this is the overlooked core of Minghella's film.

\section{WITH A LITTLE SEX}

Highsmith's engagement strategy entails that Tom is not a victim but a perpetrator. She facilitates readers' alignment with her character by employing a highly subjective narration. Moreover, Highsmith creates an overarching mechanism that encourages a motivational alignment with her protagonist as he searches for a new identity. Unlike Minghella, she does not attempt to appeal to our sympathies by relying on Tom's victimization, virtue displays or moral disengagement cues. Instead, she allows for the readers' and Tom's realizations to occur concurrently.

The changes Minghella introduced into Highsmith's narrative have prompted accusations that he "larded the character with a conscience" 
(Minghella, Interviezes 97). Such conclusions are indicative of a narrowly focused interpretation that may have been induced by Minghella's pursuit of sympathetic identification. Tom's incapacity to form meaningful relationships, I argue, renders him more akin to Highsmith's sociopath. For this reason, Minghella's narrative of a misguided search for acceptance may have been better served by an empathy focused strategy. That said, perhaps recognition of Minghella's biblical allusions provides an interpretative framework that is more conducive to a broader response.

The tendency of critics and scholars to favour the sexual elements of Minghella's narrative narrows their analytic scope. As a result, the film's complex protagonist is often reduced to a single characteristic. In readings such as those made by Edward A. Shannon, lust eclipses Tom's desire for family and acceptance. This is a divergence from Minghella's stated objective. While the filmmaker's protagonist seeks "love in all the wrong places" the story's tragedy ultimately transpires because of a father's withdrawal from his prodigal son (Minghella, Interviewes 68). If sex obscures this part of the narrative, it might frustrate Minghella's sympathy elicitation efforts. That said, the filmmaker's gravitation towards an industry-tested formula might be to blame. The notion brings to mind the opening scene from Preston Sturges's film Sullivan's Travels (1941). There, a Hollywood director explains his vision to his producers: "I wanted to make you something outstanding, something you could be proud of, something that would realize the potentialities of the film as the sociological and artistic medium that it is." The studio executives are unimpressed. "With a little sex in it?" one of them asks. "With a little sex in it," the director relinquishes.

Considering both Ripleys, it might be tempting to pass judgment on which of the two engagement strategies has proved more successful. Among other things, affective disposition theory has attempted to explain the "media-enjoyment process" (Janicke and Raney 486). The discussions concern several factors, including moral assessment, sympathy and character identification. On the other hand, recent research demonstrates the importance of both empathy and sympathy in "influencing social attitudes" (see Małecki et al.). It does not, however, provide any evidence in favour of either of the phenomena. Thus it is difficult to defend either encouragement of sympathy or elicitation of empathy based on a single theorization such as this paper. However, considering the discrepancy between Minghella's stated intentions and the actual effect achieved in his film, it is clear that both storytellers and researchers would benefit from empirical findings that could help assess the general effectiveness of different audience engagement strategies. 


\section{Works Cited}

American Psychiatric Association. "Antisocial Personality Disorder." Diagnostic and Statistical Manual of Mental Disorders, American Psychiatric Publishing, 2013, pp. 659-63. https://doi.org/10.1176/ appi.books. 9780890425596

Batson, Daniel. Altruism in Humans. Oxford UP, 2011. https://doi. org/10.1093/acprof:oso/9780195341065.001.0001

Bronski, Michael. "The Talented Mr. Ripley Review." Cinéaste, vol. 25, no. 3, 2000, pp. 41-43.

Booth, Wayne C. The Rhetoric of Fiction. U of Chicago P, 1961.

Branigan, Edward. Point of View in the Cinema: A Theory of Narration and Subjectivity in Classical Film. Mouton Publishers, 1984.

Carrol, Noel. "On Some Affective Relations between Audiences and the Characters in Popular Fictions." Empathy, edited by Amy Coplan and Peter Goldie, Oxford UP, 2011, pp. 162-84. https://doi.org/10.1093/ acprof:oso/9780199539956.003.0012

Carrol, Noel. The Philosophy of Motion Pictures. Blackwell Publishing, 2008. Coplan, Amy. "Empathic Engagement with Narrative Fictions." The Journal of Aesthetics and Art Criticism, vol. 62, no. 2, 2004, pp. 141-52. https://doi.org/10.1111/j.1540-594X.2004.00147.x

Dixon, Peter, and Marisa Bortolussi. "Literary Communication: Effects of Reader-Narrator Cooperation." Poetics, vol. 23, 1996, pp. 405-30. https://doi.org/10.1016/0304-422X(95)00007-7

Eisenberg, Nancy. "Empathy and Sympathy: A Brief Review of the Concepts and Empirical Literature." Anthrozoös: A Multidisciplinary Journal of the Interactions of People and Animals, vol. 2, no. 1, 1988, pp. 15-17. https://doi.org/10.2752/089279389787058226

Fludernik, Monika. An Introduction to Narratology. Translated by Patricia Häusler-Greenfield and Monika Fludernik. Routledge, 2009. https:// doi.org/10.4324/9780203882887

Gaut, Berys. "Empathy and Identification in Cinema." Midwest Studies in Philosophy, vol. 34, 2010, pp. 136-57. https://doi.org/10.1111/j.14754975.2010.00211.x

Highsmith, Patricia. The Talented Mr. Ripley. Coward-McCann, 1955.

Iglesias, Karl. Writing for Emotional Impact: Advanced Dramatic Techniques to Attract, Engage, and Fascinate the Reader from Beginning to End. WingSpan, 2005.

Janicke, Sophie H., and Arthur A. Raney. "Exploring the Role of Identification and Moral Disengagement in the Enjoyment of an Antihero Television Series." Communications, vol. 40, no. 4, 2015, pp. 485-95. https://doi. org/10.1515/commun-2015-0022 
Keen, Suzanne. Empathy and the Novel. Oxford UP, 2007. https://doi. org/10.1093/acprof:oso/9780195175769.001.0001

Kotovych, Maria, Peter Dixon, Marisa Bortolussi, and Mark Holden. "Textual Determinants of a Component of Literary Identification." Scientific Study of Literature, vol. 1, no. 2, 2011, pp. 260-91. https:// doi.org/10.1075/ssol.1.2.05kot

Małecki, Wojciech, Bogusław Pawłowski, Piotr Sorokowski, and Anna Oleszkiewicz. "Feeling for Textual Animals: Narrative Empathy Across Species Lines.” Poetics, vol. 74, 2019, pp. 1-8. https://doi. org/10.1016/j.poetic.2018.11.003

Massey, Susan. "Highsmith, Patricia (1921-95)." 100 American Crime Writers, edited by Steven Powell, Palgrave Macmillan, 2012, pp. 16570.

Minghella, Anthony. Anthony Minghella: Interviezes. Edited by Mario Falsetto. UP of Mississippi, 2013.

Minghella, Anthony. The Talented Mr. Ripley: Shooting Draft. 1999.

"Oscars." Academy of Motion Picture Arts and Sciences, https://www. oscars.org/oscars, accessed 10 Mar. 2021.

Plantinga, Carl. Moving Viewers. U of California P, 2009. https://doi. org/10.1525/9780520943919

Schenkar, Joan. The Talented Miss Highsmith: The Secret Life and Serious Art of Patricia Highsmith. St. Martin's, 2009. ePub.

Schwanebeck, Wieland. "Mr Ripley's Renaissance: Notes on an Adaptable Character." Adaptation, vol. 6, no. 3, 2013, pp. 355-64. https://doi. org/10.1093/adaptation/apt017

Shafer, Daniel M., and Arthur A. Raney. "Exploring How We Enjoy Antihero Narratives." Journal of Communication, vol. 62, 2012, pp. 1028-46. https://doi.org/10.1093/adaptation/apt017

Shannon, Edward A. "Where Was the Sex? Fetishism and Dirty Minds in Patricia Highsmith's The Talented Mr. Ripley." Modern Language Studies, vol. 34, no. 1/2, 2004, pp. 16-27. https://doi.org/10.2307/4150053

Smith, Greg M. Film Structure and the Emotion System. Cambridge UP, 2003. https://doi.org/10.1017/CBO9780511497759

Smith, Murray. Engaging Characters: Fiction, Emotion, and the Cinema. Clarendon, 1995.

Stout, Martha. The Sociopath Next Door: The Ruthless vs. the Rest of Us. Broadway, 2005.

Sullivan's Travels. Directed by Preston Sturges, performances by Veronica Lake and Joel McCrea, Paramount Pictures, 1941.

Tan, Ed S. Emotion and the Structure of Narrative Film. Film as an Emotion Machine. Translated by Barbara Fasting. Lawrence Erlbaum Associates, 1996. 
The Talented Mr. Ripley. Directed by Anthony Minghella, performances by Matt Damon, Jude Law and Gwyneth Paltrow, Miramax Films, 1999. Vaage, Margrethe Brun. "Fiction Film and the Varieties of Empathic Engagement." Midwest Studies in Philosophy, vol. 34, 2010, pp. 15879. https://doi.org/10.1111/j.1475-4975.2010.00200.x

Williams, Michael. "Plein Soleil and The Talented Mr Ripley: Sun, Stars and Highsmith's Queer Periphery.” Journal of Romance Studies, vol. 4, no. 1, 2004, pp. 47-62. https://doi.org/10.3828/jrs.4.1.47

Wilson, Andrew. Beautiful Shadow: A Life of Patricia Highsmith. Bloomsbury, 2003.

Zillmann, Dolf, and Joanne R.Cantor. "A Disposition Theory of Humor and Mirth." Humour and Laughter: Theory, Research and Applications, edited by Anthony J. Chapman and Hugh C. Foot, Wiley, 1976, pp. 93-115. https://doi.org/10.4324/9780203789469-6

Lech Zdunkiewicz is currently enrolled in the $\mathrm{PhD}$ program at the University of Wrocław. His primary interests include narrative techniques in modern American literature and film. His MA thesis for the University of Wroctaw was a finalist of the MA Thesis Award of the Polish Association of American Studies for 2017. His current research concerns character engagement strategies in literature and film. Since 2008 he has worked in independent and studio film productions.

https://orcid.org/0000-0002-6735-2989

mr.zdunkiewicz@gmail.com 